\title{
Recent advances in novel remediation processes towards heavy metals removal from wastewaters
}

\author{
Varun Dhiman ${ }^{1,}{ }^{*}$, Deepak Pant ${ }^{2}$, \\ Santosh Kumari ${ }^{3}$ and Sandeep Kumar ${ }^{4}$
}

${ }^{1}$ Waste Management Laboratory, School of Earth \& Environmental Sciences, Central University of Himachal Pradesh, Shahpur, Himachal Pradesh 176206, India ${ }^{2}$ School of Chemical Sciences, Central University of Haryana, Jant-Pali, Mahendergarh, Haryana 123031, India ${ }^{3}$ Department of Vegetable Sciences, College of Horticulture and Forestry, NERI, Hamirpur 177001, India ${ }^{4}$ Department of Food Technology, College of Horticulture and Forestry, NERI, Hamirpur 177001, India

\begin{abstract}
Increasing demand and overexploitation of natural resources leads to their quality degradation. Water is such a natural resource whose mismanagement causes loss of its natural integrity and therefore, it faces serious pollution concerns. Apart from hydrosphere, different environmental compartments severely facing the challenge of environmental degradation. Heavy metals are natural but anthropic factors release them in the environment including water system which is highly prone to their toxic effects. Due to the direct toxic impact of heavy metals on water sources, special focus is required to check their presence. The methods developed in the past for their remediation purpose were not so efficient and have concerns about toxic byproducts generation. Therefore, to fight with the persisting challenge, cost-effective, highly efficient, and eco-friendly remedial processes and technological advancements have been developed in the recent past and present scenarios. This chapter summarizes the recent advances in novel remediation processes toward heavy metal removal from wastewater. A case study of Rāmgangā aquifer was also discussed.
\end{abstract}

\section{Keywords}

Environment, Heavy metals, Metal ions, Remediation, Wastewater 
Heavy metals definition: "Heavy metals are natural elements characterized by their high atomic mass and relatively high density compared to water".

\section{Introduction}

Water is a unique gift by Mother Nature to all living beings for their survival (Kumar and Joshiba, 2019). It is used as an imperative resource by human beings for drinking, agriculture, industries, hydro-energy, and various other important life-sustaining and recreational activities (Sanghavi and Balaji, 2013). Unfortunately, humans harness the water resources in an unsustainable way and degraded its natural quality by its human-induced activities such as unsustainable industrial growth, unplanned infrastructure development, deforestation, discharge of contaminated effluent in water bodies and agricultural runoff containing synthetic pesticides and fertilizers (Dhiman, 2020a; Iyer and Giri, 2020; Meybeck and Chapman, 2006; Pinto and Oliveira, 2020). Previously, USEPA (2012) report confirms the higher release of pollutants in the water bodies in recent decades which certainly going to affect the under-developed nations in the coming years (Adejumoke et al., 2018; Sikder et al., 2013). This unsustainable approach of rapid growth and industrialization has resulted in the release of heavy metals in the different environmental spheres of the ecosystem, thus disturbs their normal functioning. The water contamination by heavy metals is one of the major environmental concern nowadays. Naturally, heavy metals are introduced in the water sources through the soil-rock weathering, volcanic eruptions (Bradl, 2005; Buccolieri and Turnone, 2006) while local rock-mineral mining, processing and synthetic agricultural pesticides, etc. are some of the anthropogenic routes of heavy metals transport in the water sources (Quansah and Luginaah, 2014; Kumar et al., 2019; Hernández et al., 2020).

Huge population burden, technological advancement, agricultural-domestic runoff, and excessive natural resource exploitation are some of the major contributors to environmental pollutants. Also, Industrial effluent discharge and dumping sites along the river banks introduced these water pollutants, therefore, causes serious concern for water pollution. Among the variety of pollutants released, heavy metals constitute a highly toxic and environmentally persistent group (Masindi and Muedi, 2018; Wuana and Okieimen, 2011). These metal pollutants are known for their higher-level molecular density, toxicity, non-biodegradability, and bioaccumulation potential (Khan and Ilahi, 2019). They usually existed in parts per million (ppm) or parts per billion (ppb) concentration ranges in water bodies, still pose a higher level of toxic threat to the resident population (Pugazhenthiran et al., 2016). USEPA listed chromium, arsenic, zinc, cadmium, copper, mercury, and nickel as the class B metals which are usually widely spread, non-essential, and highly toxic (Moo-Young, 2019). The description of the broad classification of heavy metals is represented in Figure 1.

According to the World Health Organization (WHO) standards, permissible limits of heavy metals in drinking water is as follows, Mercury- $0.010 \mathrm{mgL}^{-1}$, Arsenic- $0.010 \mathrm{mgL}^{-1}$, Lead- $0.010 \mathrm{mgL}^{-1}$, Zinc- 3.000 


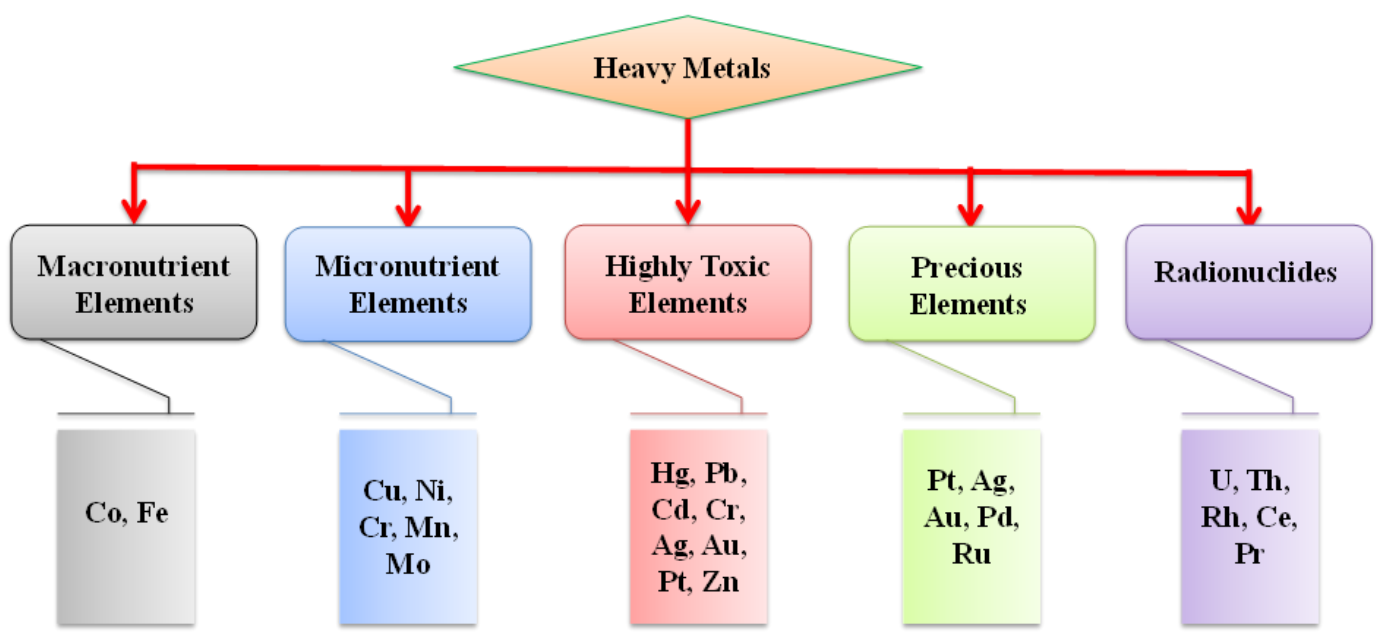

Figure 1. Schematic representation of the broad classification of heavy metals (Koller and Saleh, 2018;

Selvi et al., 2019).

mgL-1, Cadmium- $0.003 \mathrm{mgL}^{-1}$, respectively (Duwiejuah et al., 2015). Similarly, Comprehensive Environmental Response Compensation and Liability Act of United States of America set its standards for maximum permissible limits of heavy metals in an aqueous medium for chromium, arsenic, cadmium, mercury, lead and, silver to $0.01,0.01,0.05,0.002,0.015$ and, $0.05 \mathrm{mgL}^{-1}$, respectively (Selvi et al., 2019). It is evident from the fact that, on exceeding these permissible limits, heavy metals raises a serious environmental threat in the form of environmental toxicity, development of life-threatening ailments in human beings (e.g. neural disorders, kidney failure, hypertension, low immunity, physical disability, cancers, reproductive disorders, etc.) and other living biotas (Verma, 2020). Some heavy metals are important for various biological functions in humans and animals within a defined concentration range (Fisher and Gupta, 2020). Despite their biological functioning in humans and animal metabolism, their chemical co-ordination and redox reaction chemistry enable them to induce stress by free radical generation in the organism's body which is highly toxic to them (Dhiman, 2020b; Ferdinand et al., 2019). Besides, their bioaccumulation potential is also a triggering factor in inducing toxicity. Studies reveal that freshwater animals such as fish, phytoplankton's and, zooplankton's are very prone to heavy metals as they bio-accumulate them in their body tissues (Achary et al., 2020). Recently, a study on Ganga water and its fishes explores the realistic situation of heavy metals bioaccumulation. It was found that heavy metal concentration trend in Ganga river water was $\mathrm{Zn}>\mathrm{Cu}$ $>\mathrm{Pb}>\mathrm{Cd}>\mathrm{Cr}$ in almost all targeted fish species.

Zinc was found to be $0.29 \pm 6.45 \mu \mathrm{g} / \mathrm{g}$, Copper- $11.05 \pm 2.65 \mu \mathrm{g} / \mathrm{g}$ in liver cells, lead- $4.77 \pm 0.34 \mu \mathrm{g} / \mathrm{g}$, Cadmium- $2.54 \pm 0.33$ and chromium- $1.74 \pm 0.31$ (Maurya et al., 2019). Due to their potential toxicity 
and environmental hazards, heavy metals must be remediated from the environment and to bring these highly toxic pollutants within the permissible limits set by the international organizations. During the advancement processes of heavy metal remediation from water sources, many physical, chemical, and biological methods were developed. Despite their effective role in heavy metals bioremediation, some loopholes like a large amount of reagent requirement, toxic sludge generation, higher cost, lower efficiency, unpredictable metal ion removal, etc. were observed. Research is continuously going in the direction to develop more effective and novel remedial processes toward heavy metal removal from contaminated water. Therefore, we, here in this chapter have focused to explore and discuss recent advances in the processes implied for heavy metals remediation from contaminated water. To the best of our knowledge, this is the first of its kind of chapter that summarizes recent and latest advancements in the field of heavy metals remediation.

\section{Heavy metals inception}

Different studies have documented different sources of heavy metal inception. However, there are two broad categories existed: i) Natural sources and, ii) Anthropogenic sources. Through the Natural and anthropogenic activities, heavy metals released in different environmental compartments such as soil, water, and air where they make negative interactions within the living biota and interfere with their normal behavior. Different sources have been represented in Figure 2.

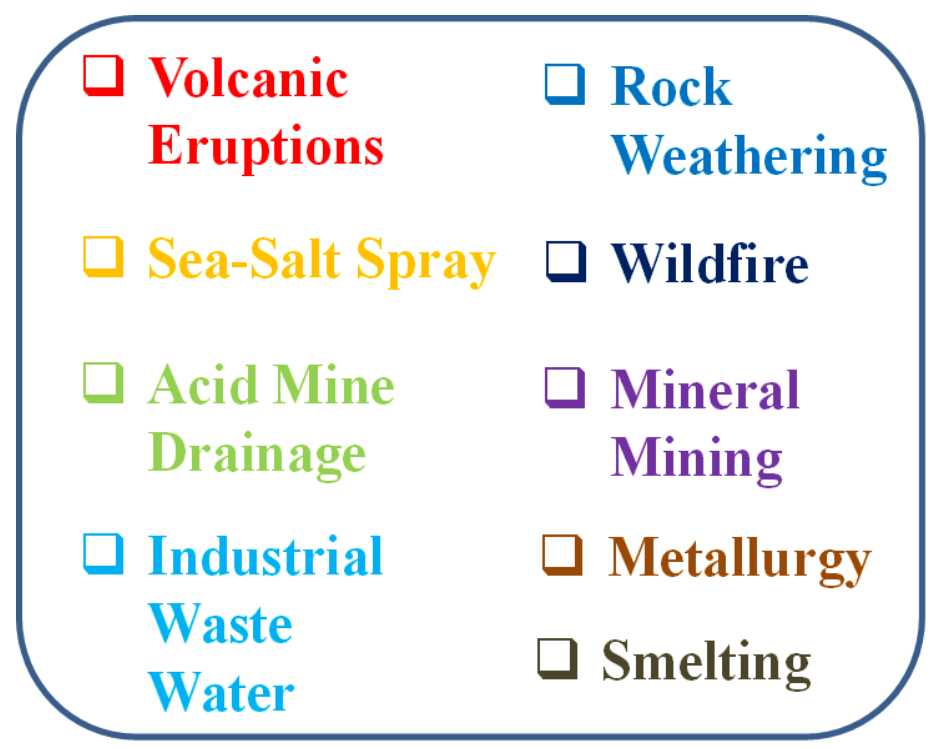

Figure 2. Diagram showing various heavy metal sources (Alloway, 2013). 


\section{Natural inception}

Volcanic eruption: The volcanic eruption is known to contain elevated concentrations of titanium, manganese, copper, and zinc. The eruption is also having a substantial amount of metal halides that became soluble and dissolved when entered in the hydrosphere. These metal halides release heavy metals in the water systems and contaminate them, therefore, induce a serious level of metal toxicity (Ma et al., 2019; Ragnarsdottir, 1994).

Rock-Sediments weathering: Studies confirm the rocks and sediments as one of the important natural sources and sink of heavy metals. In due course, rock-sediments weathering takes place under the influence of several physicochemical factors (e.g. hydrodynamics, temperature variations, amount of organic matter present, microbial interactions, reduction-oxidation chemistry, ionic behavior, salinity, particle size and, $\mathrm{pH}$ of medium) and promotes heavy metals leaching in the water system (Ali et al., 2019; Bradl, 2005; Masindi and Muedi, 2018).

Sea-salt spray: Sea-salt spray contains a significant amount of heavy metals concentration in the sea surf zone. This natural phenomenon involves the fundamental role of air which effectively transfers radionuclides and different air pollutants to the seawater from the land ecosystem. Mackay and Walker in their study observed this inland transfer of different pollutants along the Cumbrian coastline and various other sites of the Irish Sea. It has been found that the heavy metals such as $\mathrm{Al}, \mathrm{Fe},{ }^{239} \mathrm{Pu},{ }^{241} \mathrm{Pu}$, and Am constitute the major proportion of Sea-salt spray (McKay et al., 1994)

Wildfire: The remained ash after a wildfire is known to contain a fraction of heavy metals along with oxides and hydroxides of calcium, magnesium, potassium, silica, and phosphorous which are highly alkaline. Wildfires result in mineralization of organic matter which in-turn induces heavy metals transport to the water and soil, therefore, contribute to environmental contamination. Studies established the fact that the heavy metals concentration varies with the type of species and the part burned (Pereira and Úbeda, 2010).

\section{Anthropogenic inception}

Acid-mine drainage: Waste rock material when exposed to acidic water, metal leaching occurs. Acidmine drainage poses a serious environmental concern as it promotes percolation of acidic water along with nickel, cobalt, zinc, and copper like metals to the groundwater sources and hence degrades its quality (Lei et al., 2010).

Raw wastewater and sludge disposal: Different studies conducted across the globe confirm the presence of a residual concentration of organochlorine pesticides and heavy metals like zinc, lead, copper and, nickel, etc. in wastewater and sludge. Household laundry wastewater and untreated effluent from local industries are the main contributors to water pollution that release highly toxic contaminants in the hydrological system and causes water contamination (Jiries et al., 2002).

Rock-minerals mining: Studies establish the role of Rock-Minerals Mining at a local and commercial 
level in causing water bodies pollution by releasing $\mathrm{As}, \mathrm{Cd}, \mathrm{Cr}, \mathrm{Cu}, \mathrm{Ni}, \mathrm{Pb}$ and, $\mathrm{Zn}$ like heavy metals in the surrounding water bodies and underground water sources. Therefore, it plays a significant role in the destruction of the fragile water ecosystem (Wei et al., 2018).

Metallurgical waste: The metallurgical industry produces diverse kinds of hazardous waste where heavy metals constitute the major proportion. The water extracts of metallurgical slags of copper and zinc itself contain $\mathrm{Cd}, \mathrm{Cr}, \mathrm{Cu}, \mathrm{Ni}, \mathrm{Pb}$ and, $\mathrm{Zn}$ metals in different concentrations ranges from 5.19 to $<0.050 \mathrm{mg} / \mathrm{dm}^{3}$. These metals are well known for their higher leaching potential and therefore pose a significant environmental risk (Mizerna, 2016).

\section{Atmosphere-Soil-Water distribution cycle}

The rapid industrial growth and expansion of urban areas increase the rate of heavy metal pollution in the water sources. For example, the river ecosystem is found to be more prone to metal pollution (Sharma et al., 2020). These toxic metals undergo different interactions with environmental compartments of soil, air, water, etc. within a distribution cycle and therefore moved and transport from one environmental sphere to another (Kennish, 1996; Masindi and Muedi, 2018). In the case of different heavy metals, mercury, arsenic, and chromium are one of the toxic and known heavy metals which have several industrial and household uses (Jaishankar et al., 2014).

Therefore, to explore the interaction and distribution of heavy metals with different environmental spheres, these metals are a suitable example to represent the atmosphere-soil-water distribution cycle.

\section{Mercury}

Mercury shares the same periodic group with other metals like zinc and cadmium (Jensen, 2003). It existed as elemental mercury, mercury (I) chloride and, mercury (II) chloride in nature (Park and Zheng, 2012). As for their water solubility, mercury (I) chloride showing low solubility; mercury (II) chloride is readily water-soluble while its elemental form is non-soluble (Park and Zheng, 2012). It undergoes methylation when entered in fresh or seawater. Some bacterial strains of Pseudomonas spp. and sulfate triggers the mercury methylation under aerobic conditions (Ma and Wang, 2019). Mercury enters the atmosphere in the form of vapors and volatile toxic form from industrial emissions, fossil fuel burning and, gold mining activities. Upon entering, it starts its dry deposition in the air where it undergoes methylation and demethylation processes.

When rain occurs, it comes to the terrestrial ecosystem with its water droplets and surface runoff during rain paves the entry of mercury in the natural water sources (Figure 3). In waters, it bioaccumulates in fishes and other freshwater species thereby entered in the food chain of the living system (Berlin et al., 2015; Siddiqi, 2018). 


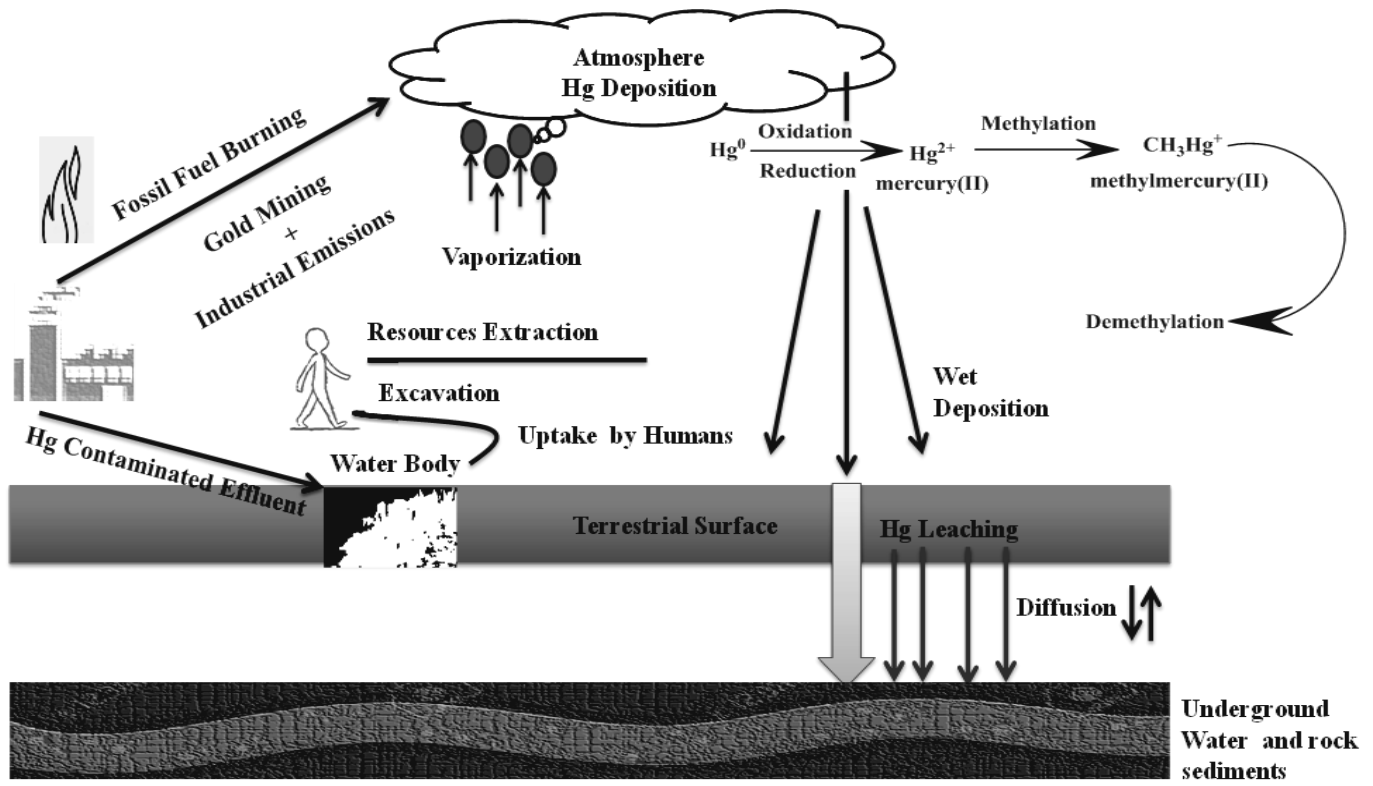

Figure 3. Schematic representation of the Atmosphere-Soil-Water Distribution cycle of mercury (Modified after: Berlin et al., 2015; Selin, 2009; Siddiqi, 2018).

\section{Arsenic}

Arsenic is one of the most toxic heavy metals that existed in the environment (Jaishankar et al., 2014). It is exposed to humans through underground water systems, used for drinking purpose (Shankar et al., 2014). Bangladesh and India's state of West Bengal are the two most arsenic affected regions across the world (Chakraborty et al., 2015). Arsenic finds its diverse applications in paint industries, pesticides, herbicides, cotton industries as a desiccant, and as wood preservatives (Lim et al., 2014). As far as their oxidation states are concerned, it exists as a trivalent and pentavalent form. The trivalent form of arsenic is sixty times more toxic than its pentavalent form (Flora, 2014; Gomez-Caminero et al., 2001; Ratnaike, 2003).

Anthropogenic activities like extraction and excavation of minerals release arsenic in the environment where they mix with surface runoff during wet deposition and thereby enter into water systems. It also concentrates on the animal's tissues and causes extreme toxic effects in the exposed animals through transfer and movement across the food chain system (Mandal, 2017). A schematic representation of the Atmosphere-Soil-Water Distribution cycle of arsenic is represented in Figure 4. If we studied the redox chemistry of arsenic, it is a proven fact that these redox reactions decide the chemical speciation of arsenic and its derivatives in a particular environment. The $\mathrm{pH}$ level of any environmental medium in particular influences its chemical interactions with environmental components. Also, the bioavailability 


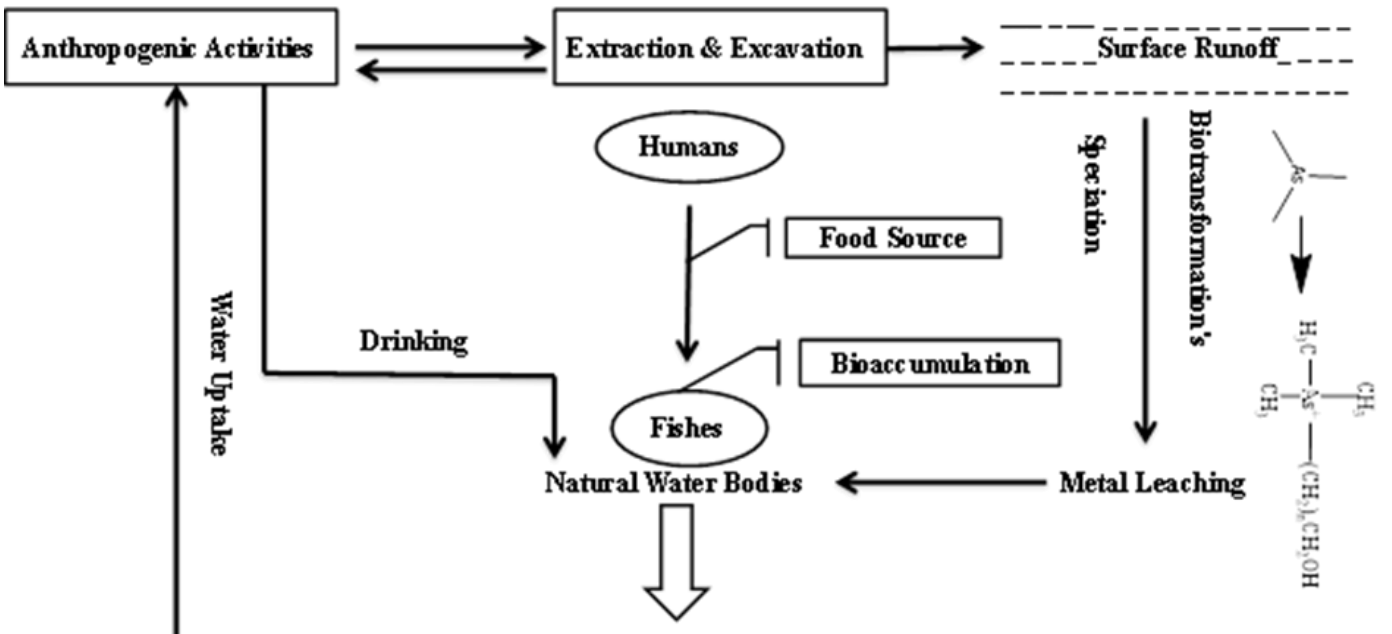

Underground Water + Rock Sediments

Figure 4. Schematic representation of the Atmosphere-Soil-Water Distribution cycle of arsenic (Modified after: Chatterjee et al., 2017; Masuda, 2018).

of arsenic in different environmental spheres depends upon the transformation reactions of pentavalent and trivalent forms of arsenic. Methylation reactions of arsenic are represented in Figure 5. Here, trimethylarsine is transformed into dimethylarsinous acid and trimethylarsino fatty alcohol. The trivalent arsenic bio-transforms with the catalytic actions of arsenic (III) methyltransferase into MNA (Zhu et al., 2017).

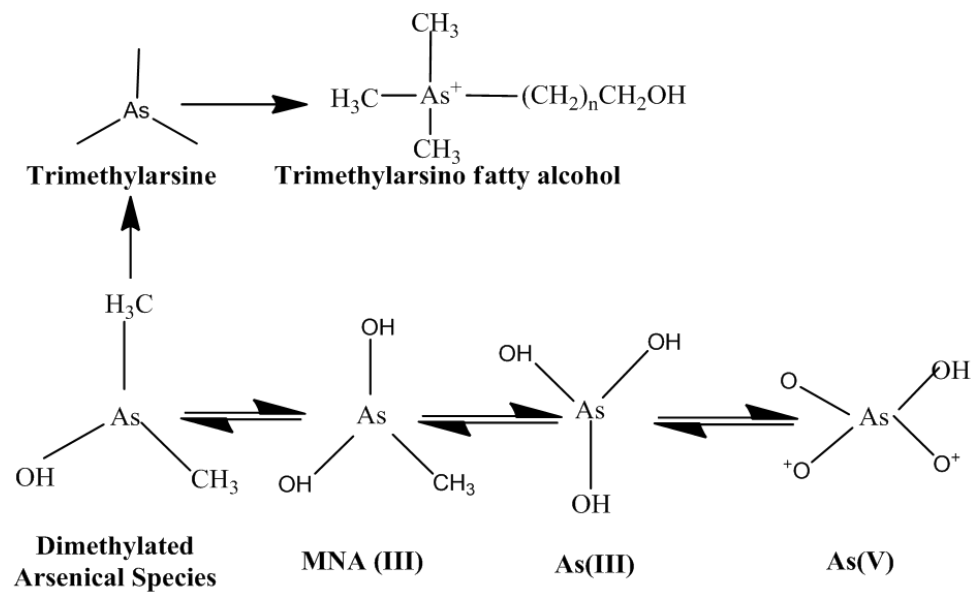

Figure 5. Schematic representation of Redox reactions of arsenic and synthesis of organoarsenicals (Source: Zhu et al., 2017). 


\section{Chromium}

Chromium is considered as one of the most toxic and pervasive environmental pollutant (Oliveira, 2012). Its hexavalent form is categorized as group 1 carcinogen because it has a high capacity to initiate complex stress-inducing reactions in the animal's body and thereby causes cancer in the body (Pohanish, 2017). Chromium also exists in its trivalent form which finds its place in nutritional supplementation (Cefalu and $\mathrm{Hu}, 2004$ ). Chromium vaporizes from industrial emissions and enters into an atmospheric component of the environment. Also, industrial effluents containing chromium slag are discharged into natural water bodies, thereby, polluting them to a serious extent (Owlad et al., 2009). The trivalent and hexavalent form of chromium also mixes in the groundwater resources through leaching and contaminate them (Figure 6) (Das and Mishra, 2008). The trivalent form of chromium is oxidized at higher temperatures. It requires an alkaline medium for its oxidation (Peng et al., 2019). The schematic representation of oxidation reactions of chromium (III) ion is given in Figure 7.

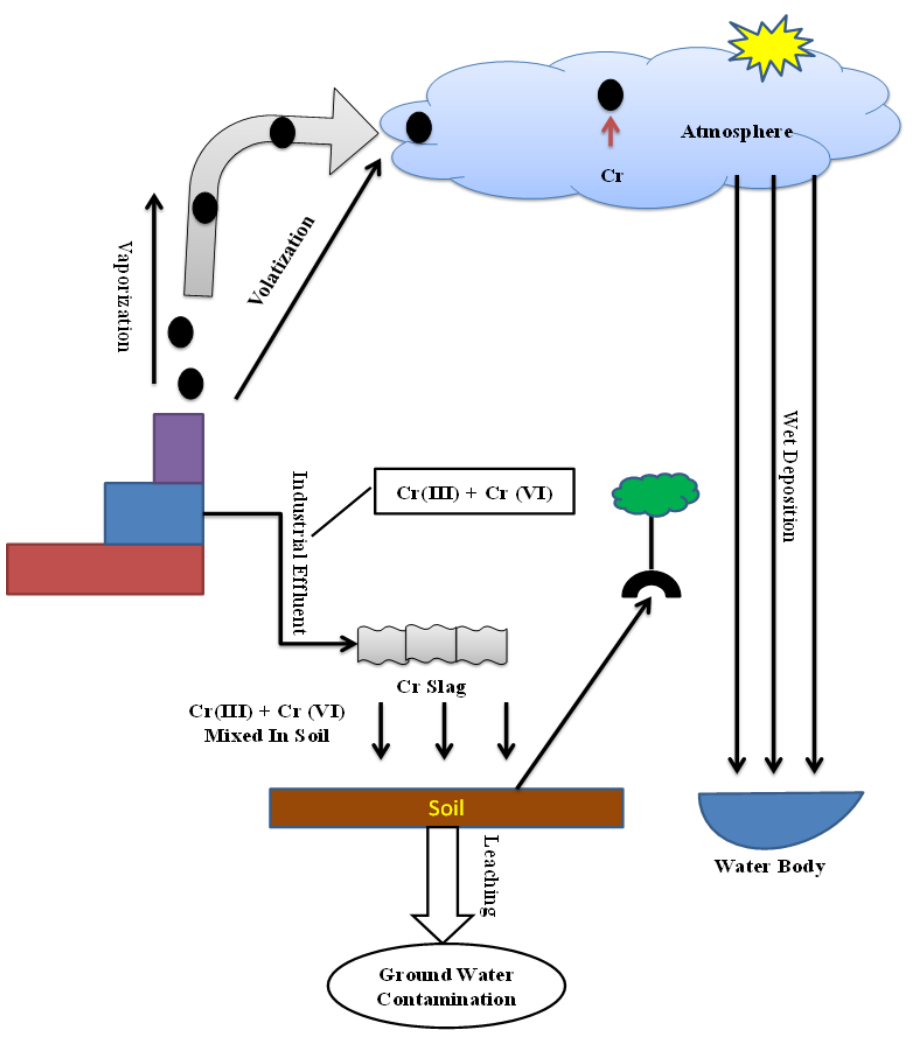

Figure 6. Schematic representation of the Atmosphere-Soil-Water Distribution cycle of Chromium (Sources: Avudainayagam et al., 2003; Bartlett, 1991). 


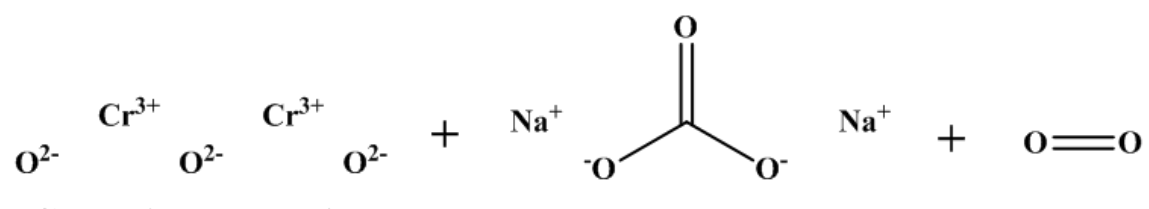

Chromium(III) oxide

Sodium carbonate

oxygen

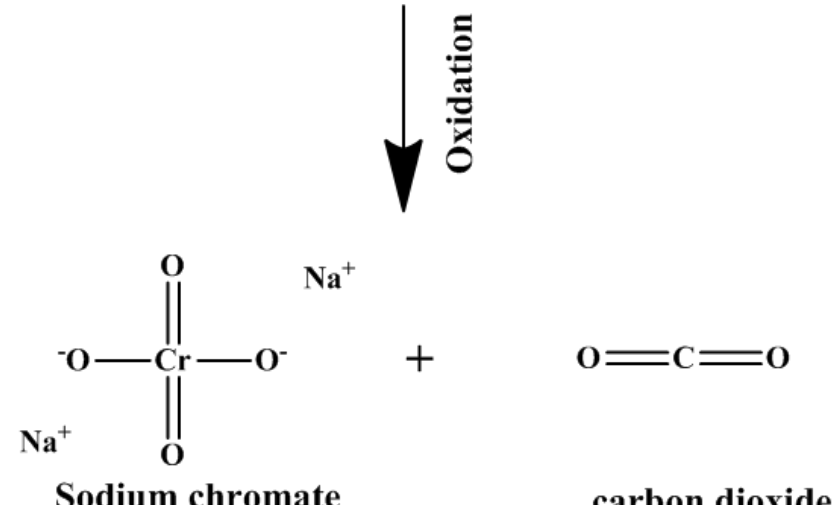

Figure 7. Schematic representation of oxidation of Cr(III) ion (Modified after: Panichev et al., 2008).

\section{Heavy metals chelation}

Chelation of heavy metals in the environmental spheres depends upon the basics of coordination chemistry. Chelating agents are organic or inorganic in their chemical nature. They attracted to specific heavy metal ions and binds with them to form a complex ring-like structure, termed as "chelate" (Tandon and Khandelwal, 1982). Chelators used for target heavy metals such as palladium, cadmium, copper, mercury, zinc, nickel, etc. (Hong et al., 2002). They are known for their high specificity and complexing power with the target heavy metal. These chelators play their important role in heavy metals extraction from water and soil and therefore, help in heavy metals removal (AlQahtani, 2017). For example, a well-known metal chelator, EDTA, is widely used as a metal chelator because of its higher level of complexing power (Oviedo and Rodríguez, 2003). But in due course, several metal chelators have been developed (Figure 8) which are strong enough and desirable for specific metal targeting by adding additional cations like $\mathrm{Ca}^{2+}$ and $\mathrm{Fe}^{3+}$. They develop metal precipitates with the target heavy metals and therefore, heavy metals can be easily removed.

However, effective heavy metal removal is still a challenge and various new processes and techniques have been developed and some are under the process of development. All these processes and techniques are discussed in detail in the further sections of the chapter. 

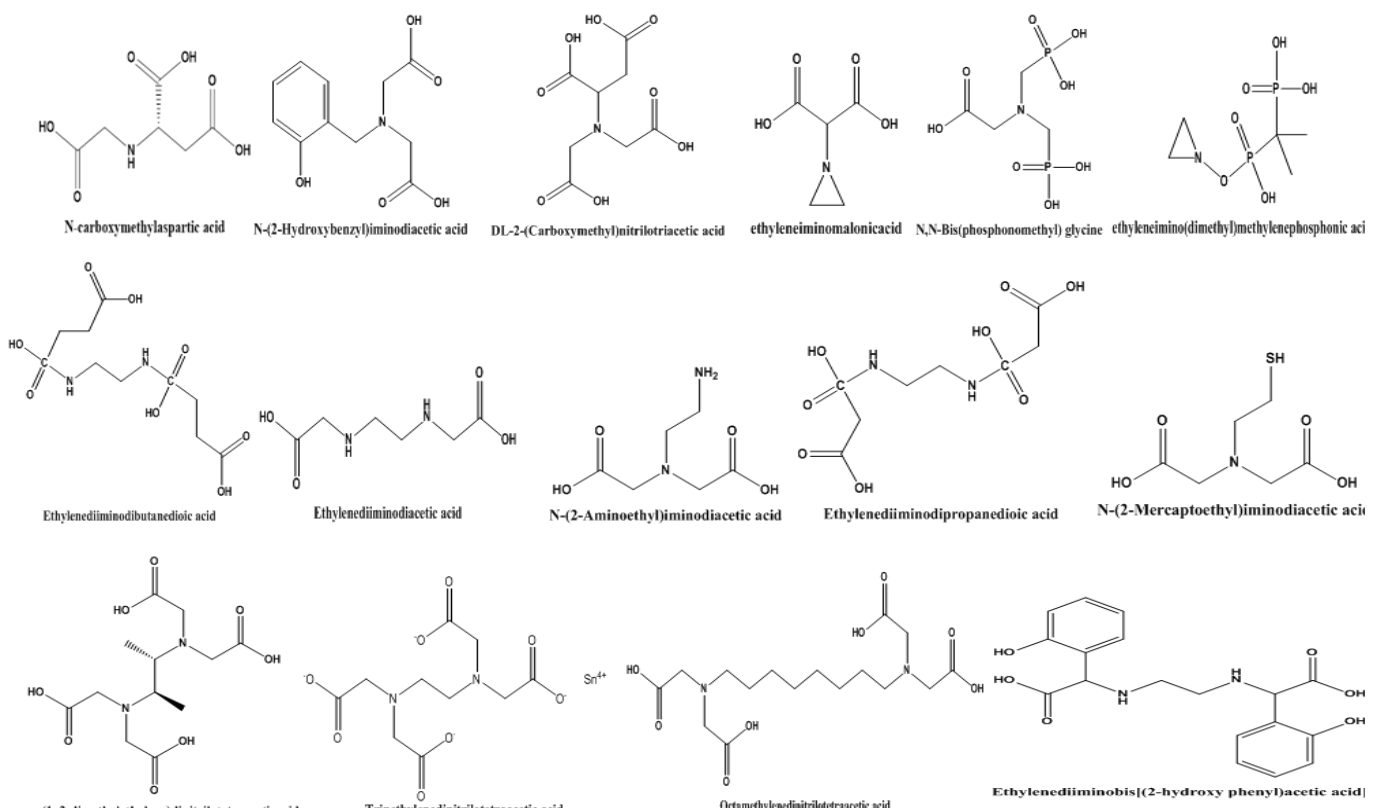

Ethylenediiminodiacetic acid

$\mathrm{N}$-(2-Aminoethyl)iminodiacetic acid
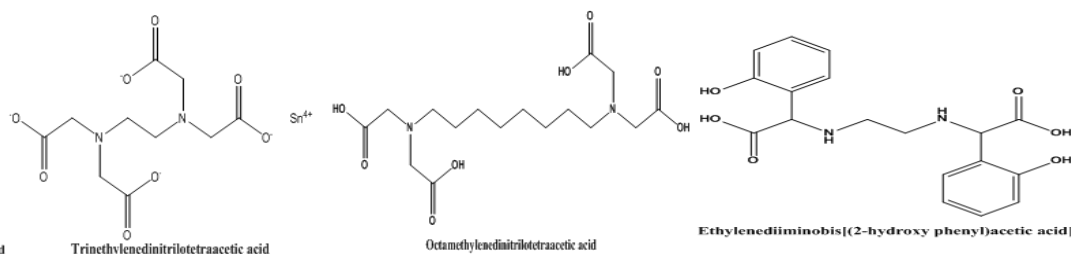

Figure 8. Chemical structures of synthesized metal-chelators (Source: Hong et al., 2002).

\section{Case study of Rāmgangā aquifer heavy metal pollution}

Groundwater sources are the purest form of water beneath the earth's surface (Abdullahi and Garba, 2015). But heavy metal pollution raises serious environmental concerns toward the purity of groundwater. A recent study has been conducted on Rāmgangā aquifer which shows the drastic condition of water pollution due to heavy metal contamination. The area of Rāmgangā basin is $\sim 4120$ square $\mathrm{km}$ and is situated in the Indian state of Utter Pradesh, district Bareilly (Tripathi, 2017). The studied area is highly significant concerning industrial developments viz. small-scale industries and expanding urban developments. This will raise the demand for water to a higher level which in turn causes water quality degradation due to its overexploitation. The industrial discharge from small scale industries was found to be the major contributor of water pollutants. This will eventually lead to a higher concentration of a variety of heavy metals in the aquifer water and rendered the water source unfit for human use. The study concluded that the rising concentration of zinc and nickel in aquifer water is a prime matter of concern. Also, the trace amount of $\mathrm{Ca}^{2+}, \mathrm{Mg}^{2+}$, and $\mathrm{HCO}_{3}{ }^{2-}$ were also found there. With zinc and nickel, equal proportions of other heavy metals were determined in the water samples but the heavy metals concentration varies with the seasonal monsoon changes. The following concentration ranges of $\mathrm{Cu}-0.001$ to 0.183 (premonsoon) and 0.001 to 0.305 (postmonsoon), Mn- 0.11 
(premonsoon) and 0.0166 to 1.308 (postmonsoon), $\mathrm{Zn}-0.075$ to 0.146 (premonsoon) and 0.156 to 2.245 (postmonsoon), Ni- 0.247 to 0.976 (premonsoon) and 0.294 to 1.246 (postmonsoon), Co- 0.143 to 0.624 (premonsoon) and 0.011 to 0.261 (postmonsoon), Cd- 0.06 to 0.299 (premonsoon) and 0.091 to 0.303 $\mathrm{mgL}^{-1}$ (postmonsoon), determined by the researchers. However, the higher $\mathrm{Zn}$ and Ni concentrations in aquifer water were related to their use in pesticides and higher solubility in water, and on mixing with agricultural runoff, it enters in the Rāmgangā aquifer water (Mazhar and Ahmad, 2020). This case study indicates the level of water pollution due to heavy metals discharge. Therefore, it the need of the hour to develop relevant and effective remedial processes of heavy metals from contaminated water sources.

\section{Novel remedial advancements in heavy metals removal}

Remedial mechanisms for heavy metals removal and their efficient extraction from the contaminated water source or any other environmental sphere is not an easy task. This is because; a huge variety of heavy metals, their metalloids, and related anionic components existed in free as well as in the form of different metal complexes in the environment. There are well known remedial methods such as precipitation (Chen et al., 2009), adsorption (Arora, 2019), ion exchange, bio-sorption (Bashir et al., 2019), solvent extraction (Černá, 1995), chemical precipitation (AbiD et al., 2011), and some membrane technologies (Khulbe and Matsuura, 2018), already existed for handling issues of heavy metals contamination but recent researches focused on the further development of advanced materials and technologies that are proved be highly effective and more efficient than the existing methods. So, to tackle the persisting challenge of heavy metals pollution with special reference to water, scientifically efficient materials, processes, and mechanisms are tested and are developed in recent times. From the latest developments, some of them are discussed below:

\section{Activated graphene nanomaterial}

Chemically, graphene is carbon originated nanomaterial with a two-dimensional atomic arrangement. It shows an $s p^{2}$ hybridization form with a 6-membered ring structure. Recently, researchers synthesized G-ASP2 nanomaterial, a graphene-based adsorbent for heavy metal removal from water sources. This newly synthesized nanomaterial was found to be highly effective in the removal of lead and iron ions from contaminated water. It has been observed that it removes iron ions from the water with $100 \%$ efficiency (Atkovska et al., 2020).

\section{Ionic liquid clay}

Recently, the latest development has been made by researchers in the field of heavy metal bioremediation. A newly modified ionic liquid clay material was developed by using triazole and 


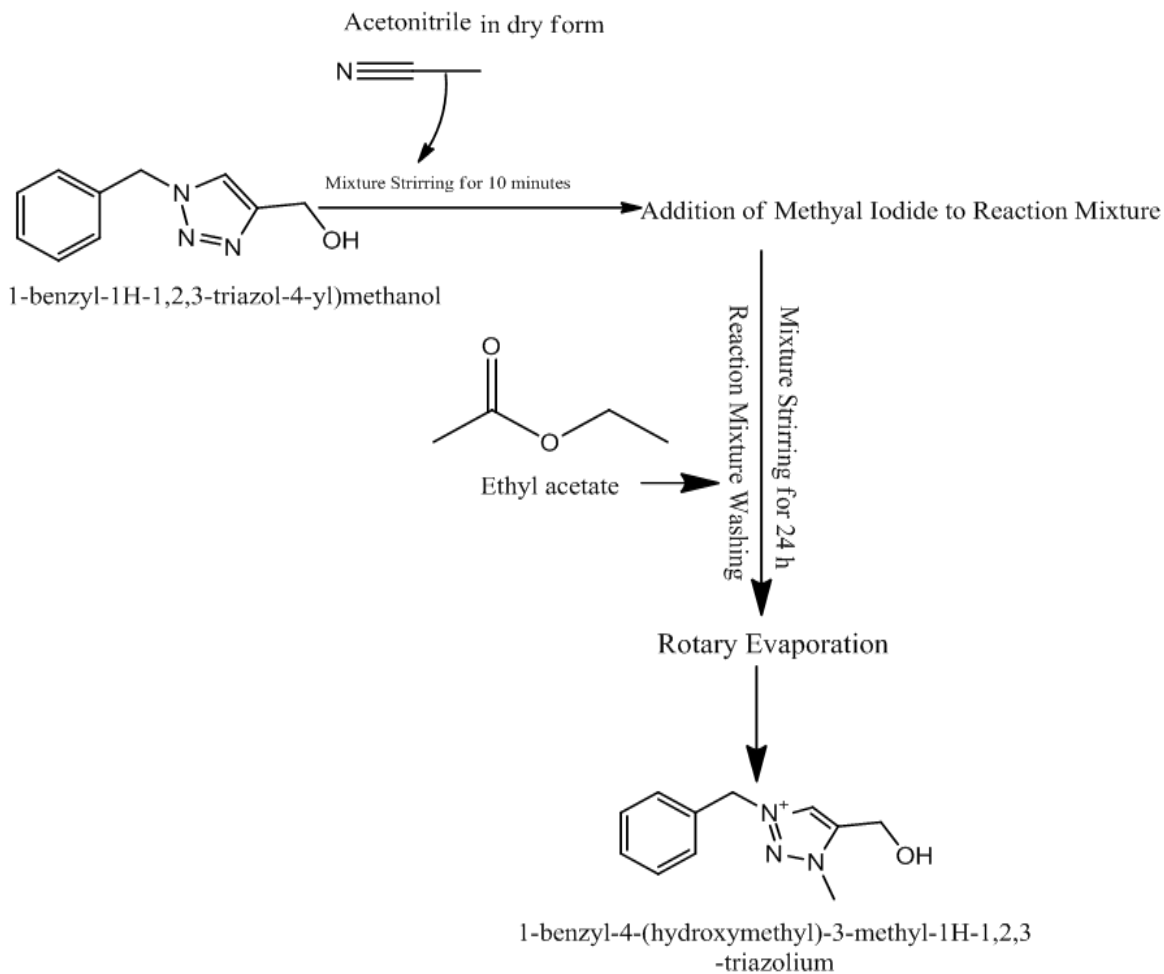

Figure 9. Schematic representation of the synthesis process of ionic liquid clay

(Adopted from: Kakaei et al., 2019).

triazolium ligands. The newly synthesized material is of high grade and alleviates heavy metals from industrial wastewater in a very efficient way by performing their adsorption. The synthesis process is represented in Figure 9.

\section{Lemon peel-based biomaterials}

Developments have been made recently in using green, ecofriendly, non-eatable agricultural parts for heavy metals adsorption from contaminated water. One such low agricultural waste i.e. lemon peel was harnessed from juice producing industries. The basic idea behind using lemon peel was the presence of pectic acid and cellulose in it. It was found that the carboxylic and cellulose functional groups provide significant binding sites for the different heavy metal ions. These functional groups act as binding receptors and therefore bind heavy metal ions of $\mathrm{Cu}, \mathrm{Cr}, \mathrm{Cd}, \mathrm{Mn}, \mathrm{Pb}$, and $\mathrm{Ni}$ at a specific site. Thereby, providing an alternative and eco-friendly process of heavy metal removal from such contaminated environments (Figure 10) where heavy metal removal is not possible. 


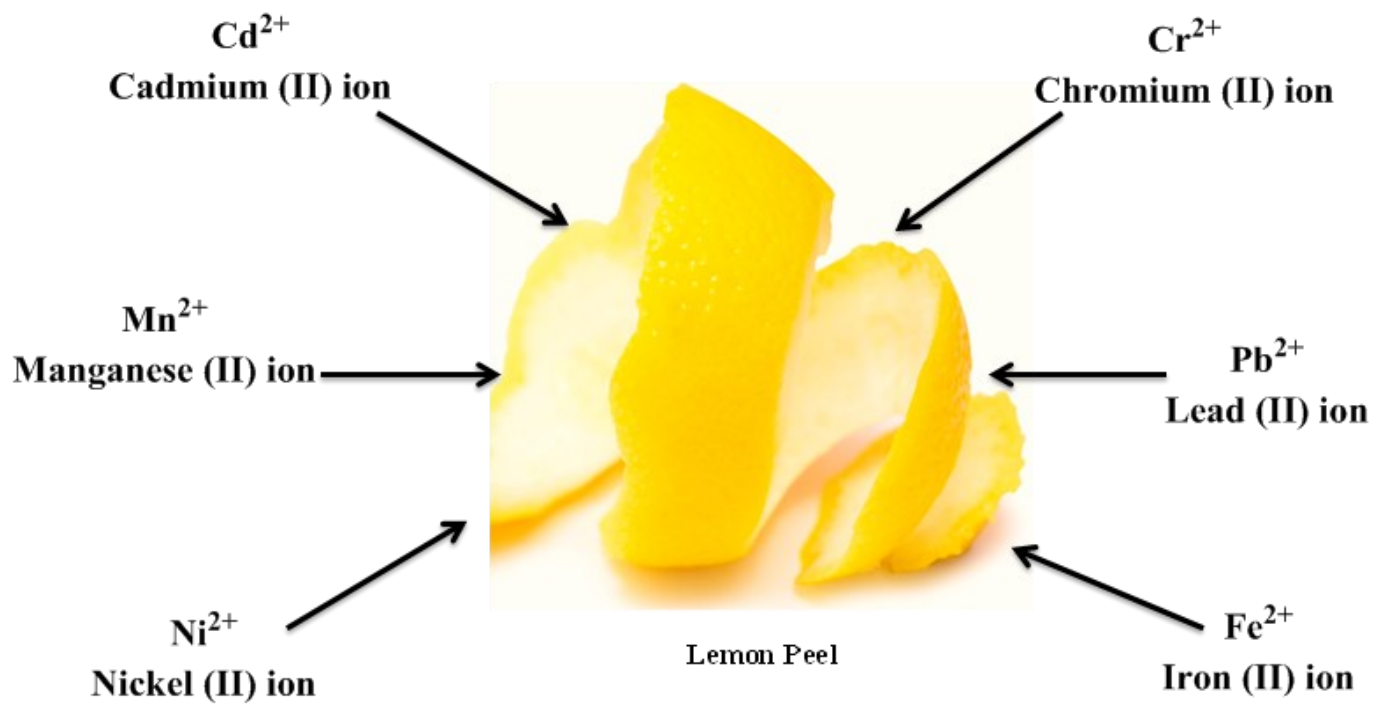

Figure 10. Lemon peels as novel bio-sorbent material for heavy metals sorption (Adopted from: Šabanović et al., 2020).

\section{Magnetic graphene oxide}

Graphene is a highly conductive, electric, and thermal form of carbon having a wide surface area of $2630 \mathrm{~m}^{2} \mathrm{~g}^{-1}$. Due to its large surface area, it is an effective material for the development of high-grade adsorbents. Therefore, researchers focus on the development of graphene-based nanoparticles with a fraction of magnetic properties. Moreover, the magnetic property of synthesized graphene oxide composites establishes their role in effective magnetic separation of heavy metal ions thereby helps in water purification processes (Farooq and Jalees, 2020).

\section{Synthetic thin film nanocomposite osmosis active layer membrane}

Synthesis of novel active thin layer osmosis membrane is the latest addition in the ongoing technological advancement in the heavy metal remediation process. The synthesis involves the preparation of a mixture of polythene glycol, polysulfone and, 1-methyl, 2-pyrrolidone in different fractions using phase inversion process, in which further addition of 1,3-phenylenediamine, graphene oxide and, 1,3,5-benzene trichloride takes place by performing interfacial polymerization process (Figure 11) along with the polyamide layer which ultimately leads to the formation of active layer membrane. This newly synthesized active layer osmotic membrane removes cadmium, chromium and, lead like heavy metals from the industrial water effluent. 


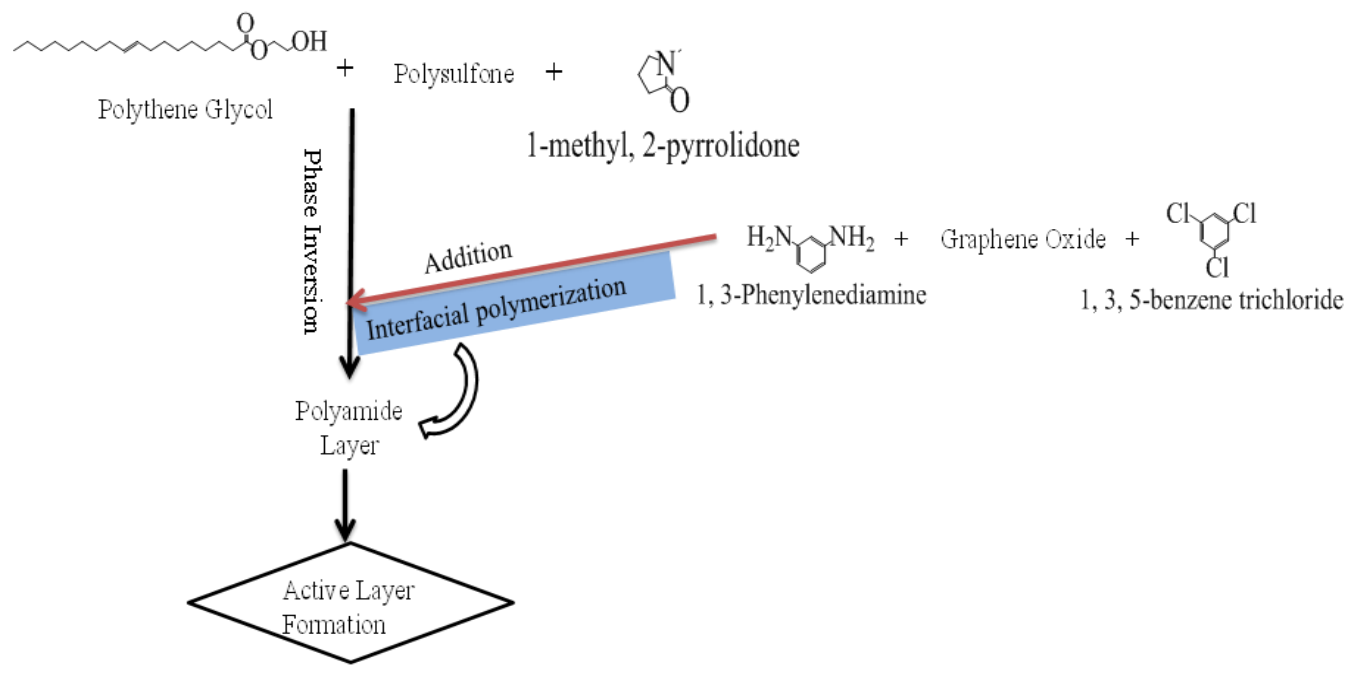

Figure 11. Schematic representation of the synthesis process of thin-film nanocomposite osmosis active layer membrane (Saeedi-Jurkuye et al., 2020).

\section{Polyaniline based materials}

In recent years, the polyaniline-based materials and products have proved their efficiency in catalysis and adsorption processes. They have a wide number of applications. Polyaniline is highly conductive and stable and can be easily prepared. Owing to its biocompatibilities and adsorption potential, it is itself used as sorbent material and is mixed with other formulations to prepared polyaniline based sorbents that are highly effective in eliminating heavy metal ions from contaminated water sources (Eskandari et al., 2020).

\section{Carbon nanotubes}

The current situation of risk posed by heavy metals in water sources demands more technological developments. One of the latest in the list is the development of multiwalled carbon nanotubes which significantly show their effectiveness in heavy metal removal. Metal ions of copper, manganese, and zinc are effectively removed from the polluted water samples. Recent studies observed their high level of heavy metal remediation potential as copper and manganese ions were observed to be removed by $79 \%$ and $78 \%$ respectively (Bassyouni et al., 2020; Nayak et al., 2020). 


\section{Two-dimensional nano-sheets}

Researchers recently synthesized water-stable 2-D zinc-based metal-organic framework nano-sheets. These sheets are found to be highly efficient for capturing heavy metals from the aquatic system with a high adsorption capacity of $253.8 \mathrm{mg} / \mathrm{g}$ for lead (II) ions and $335.57 \mathrm{mg} / \mathrm{g}$ for copper (II) ions. This much of adsorption capability of these 2-D nano-sheets is directly related to the strong affection of amino and hydroxyl groups of nano-sheets towards lead and copper metal ions (Xu et al., 2020).

\section{Biochar based sorbents}

High-temperature pyrolysis of agricultural biomass results in the formation of biochar. It is highly porous, activated, eco-friendly, and carbon-rich material which is known for its well-established role of carbon sequestration. It also produces bioenergy and acts as an agricultural fertilizer agent. Hence, it increases soil fertility. Due to its porous nature, it provides a large surface area for attachment of a variety of pollutants in the form of their complexes. The functional groups such as hydroxyl, phenolic, amino, and alkyl groups play their important role in it. Therefore, biochar is used in the development of biochar based sorbents (Shakoor et al., 2020).

\section{Magnetic iron-oxide (FeO) nanoparticles}

Recently, studies have been conducted to test the effectiveness of magnetic iron-oxide nanoparticles in heavy metals removal from the wastewater. This nano-particle is synthesized in the laboratory using hyper-branched polyglycerol polymer. This newly synthesized nano-particle was found to be very suitable in heavy metals removal because it shows a higher adsorption rate of $0.700,0.451$, and 0.790 mg.mg-1 for copper, nickel, and aluminum respectively. Therefore, it establishes itself as a promising sorbent for heavy metals sorption (Khan et al., 2020; Torres-Caban et al., 2019).

\section{Modified natural zeolites}

The use of natural zeolites as adsorbents for remediation purpose of heavy metals from the aquatic environment provides a low cost and readily available approach. Generally, zeolites are hydrated alumino-silicates of tetrahedral alumina and silica, arranged in a 3-D structure. Recently, researchers use the natural modified zeolite "clinoptilolite" as a low-cost heavy metal ions adsorbent which shows its high potential in capturing lead, chromium, cobalt, and zinc metal ions from contaminated wastewater system (Izzo et al., 2019).

\section{Photo-catalysis}

This process involves an advanced oxidation process. The mechanism of photo-catalysis is very interesting, well known for its excellent working in the remediation processes. Its use is advantageous as compared to other existed processes as it is widely working under varied temperatures and pressure 
conditions. It uses redox reaction and initiates chain reactions with heavy metal ions which ultimately leads to their molecular transformations. The photo-catalysis process uses the ultraviolet and visible light sources of wavelength ranges from 300-388 and 388-520 nm respectively (Tahir et al., 2019). This process carried forward using different semiconductors like $\mathrm{TiO}_{2}, \mathrm{ZnS}, \mathrm{CeO}_{2}$, etc. Its schematic representation is given below:

$\mathrm{SM}_{\text {cond }} \rightarrow \mathrm{SM}_{\text {cond }}\left(\mathrm{h}^{+}+\mathrm{e}^{-}\right)$

$\mathrm{M}_{\text {ion }}{ }^{\mathrm{n}+}+\mathrm{e}^{-} \rightarrow \mathrm{M}_{\text {ion }}{ }^{(\mathrm{n}-1)+}$

$\mathrm{OH}^{-}+\mathrm{h}^{+} \rightarrow \mathrm{OH}$

$\mathrm{OH}+\mathrm{RH} \rightarrow \mathrm{R}^{0}+\mathrm{H}_{2} \mathrm{O}$

$\mathrm{CO}_{2} \rightarrow \mathrm{H}_{2} \mathrm{O}+$ Mineral acid

$2 \mathrm{H}_{2} \mathrm{O}+4 \mathrm{H}^{+} \rightarrow \mathrm{O}_{2}+4 \mathrm{H}^{+}$

Where $\mathrm{SM}$ cond represents semiconductor; $\mathrm{Mion}^{\mathrm{n}+}$ is a metal ion.

\section{Fungal based electro-spun filtration membrane}

Recent studies reveal the importance of fungi in pollutant bioremediation. Using fungi, fungal based biomaterials, and adsorption systems for filtering heavy metals have been developed. The fungal strain Armillaria cepistipes (Empa 655) was used by the researchers in developing reliable biosorbent filtration membrane for heavy metal remediation. The result of using this natural filtration membrane shows $90 \%$ of removal capacity of $\mathrm{Pb}, \mathrm{Ni}, \mathrm{Cd}$, and $\mathrm{Cr}$ ions from wastewater (Tran-Ly et al., 2020).

\section{Novel coordination polymers}

The development of novel coordination complexes provides new insight in the heavy metals removal from the environment. These polymers developed by using different types of organic ligands including metal complexes. For e.g. 1,2,4,5-benzene tetracarboxylic acid is an effective chemical that allows ligand binding at its different receptor sites and therefore contributing to the synthesis of novel coordination complexes. As for their remediation potential, the latest researches found a higher level of adsorption power (99\%) for elemination of $\mathrm{Hg}$ ions from wastewater (Zhao et al., 2020).

\section{Capacitive deionization and electro-sorption}

Recently, modified and improved version of capacitive deionization and electro-sorption has gained intense popularity against toxic metals and pollutants remediation from heavily polluted water. It is also a cost-effective option and efficient technological advancement for heavy metals remediation. The mechanism of electro-sorption involves the adsorption of metal ions under the influence of the generated magnetic field. This is process very energy efficient as compared to other techniques of heavy metals removal (Chen et al., 2020). 


\section{Conclusion}

It is mandatory to have significant knowledge of the inception, environmental cycling, chemical speciation, and associated hazardous impacts of heavy metals on water sources. Upon examining the said variables, it is easy to select specific remedial processes for a specific heavy metal ion removal. Also, it helps in the development of more efficient and novel methods. Activated graphene, ionic liquid clay, lemon, biochar, and fungal based biomaterials, nanocomposite active layer, carbon nanotubes, and sheets, etc. are the latest and the best available processes for heavy metals removal from the contaminated water systems.

Conflict of interest: The authors declare no conflict of interest.

\section{Acknowledgments}

The authors are thankful to the Central University of Himachal Pradesh, Central University of Haryana, and College of Horticulture and Forestry, NERI, Dr. Yashwant Singh Parmar University of Horticulture and Forestry for providing the necessary facilities in writing of this chapter.

\section{References}

Abdullahi, M.G. and Garba, I. (2015). Effect of rainfall on groundwater level fluctuation in Terengganu. Malaysia. Journal of Geophysics and Remote Sensing, 4(2): 142-146.

AbiD, B.A., BrbootI, M.M., and Al-ShuwaikI, N.M. (2011). Removal of heavy metals using chemicals precipitation. Engineering and Technology Journal, 29(3): 595-612.

Achary, S., Panigrahi, S., Panigrahy, R.C., Prabhu, R.K., Sekar, J.K. and Satpathy, K.K. (2020). Concentration factor of metals in zooplankton and their seasonality in Kalpakkam coast, southwest Bay of Bengal. Environmental Chemistry and Ecotoxicology, 2: 12-23.

Al-Qahtani, K.M.A. (2017). Extraction Heavy Metals from Contaminated, Water using Chelating Agents. Oriental Journal of Chemistry, 33(4): 1698-1704.

Ali, H., Khan, E. and Ilahi, I. (2019). Environmental chemistry and ecotoxicology of hazardous heavy metals: environmental persistence, toxicity, and bioaccumulation. Journal of Chemistry, 2019.

Alloway, B.J. (2013). Sources of heavy metals and metalloids in soils. In Heavy metals in soils, Springer, pp. 11-50.

Armah, F.A., Quansah, R. and Luginaah, I. (2014). A systematic review of heavy metals of anthropogenic origin in environmental media and biota in the context of gold mining in Ghana. International Scholarly Research Notices, 1-10.

Arora, R. (2019). Adsorption of Heavy Metals-A Review. Materials Today: Proceedings, 18: 4745-4750.

Atkovska, K., Paunovik, P., Dimitrov, A., Lisichkov, K., Alghuthaymi, M. and Grozdanov, A. (2020). Graphene and activated graphene as adsorbents for removal of heavy metals from water resources. In Carbon Nanomaterials for Agri-Food and Environmental Applications, Elsevier, pp. 177-191.

Avudainayagam, S., Megharaj, M., Owens, G., Kookana, R.S., Chittleborough, D. and Naidu, R. (2003). Chemistry of chromium in soils with emphasis on tannery waste sites. In Reviews of Environmental Contamination and Toxicology, Springer, pp. 53-91.

Bartlett, R.J. (1991). Chromium cycling in soils and water: links, gaps, and methods. Environmental Health Perspectives, 92: 24. 
Bashir, A., Malik, L.A., Ahad, S., Manzoor, T., Bhat, M.A., Dar, G.N. and Pandith, A.H. (2019). Removal of heavy metal ions from aqueous system by ion-exchange and biosorption methods. Environmental Chemistry Letters, 17(2): 729-754.

Bassyouni, M., Mansi, A.E., Elgabry, A., Ibrahim, B.A., Kassem, O.A. and Alhebeshy, R. (2020). Utilization of carbon nanotubes in removal of heavy metals from wastewater: a review of the CNTs' potential and current challenges. Applied Physics A, 126(1): 38 .

Berlin, M., Zalups, R.K. and Fowler, B.A. (2015). Chapter 46-mercury. Handbook on the Toxicology of Metals, 1: $1013-1069$.

Bradl, H.B. (2005). Sources and origins of heavy metals. In Interface science and technology Vol. 6,. Elsevier, pp. 1-27.

Buccolieri, A., Buccolieri, G., Dell'Atti, A., Perrone, M.R. and Turnone, A. (2006). Natural sources and heavy metals. Annali Di Chimica: Journal of Analytical, Environmental and Cultural Heritage Chemistry, 96(3-4): 167-181.

Cefalu, W.T. and Hu, F.B. (2004). Role of chromium in human health and in diabetes. Diabetes Care, 27(11): 2741-2751.

Černá, M. (1995). Use of solvent extraction for the removal of heavy metals from liquid wastes. Environmental Monitoring and Assessment, 34(2): 151-162.

Chakraborty, M., Mukherjee, A. and Ahmed, K.M. (2015). A review of groundwater arsenic in the Bengal Basin, Bangladesh and India: from source to sink. Current Pollution Reports, 1(4): 220-247.

Chatterjee, S., Moogoui, R. and Gupta, D.K. (2017). Arsenic: Source, occurrence, cycle, and detection. In Arsenic Contamination in the Environment, Springer, pp. 13-35.

Chen, Q., Luo, Z., Hills, C., Xue, G., and Tyrer, M. (2009). Precipitation of heavy metals from wastewater using simulated flue gas: sequent additions of fly ash, lime and carbon dioxide. Water Research, 43(10): 2605-2614.

Chen, R., Sheehan, T., Ng, J.L., Brucks, M., and Su, X. (2020). Capacitive deionization and electrosorption for heavy metal removal. Environmental Science: Water Research and Technology, 6(2): 258-282.

Cobbina, S.J., Duwiejuah, A.B., Quansah, R., Obiri, S. and Bakobie, N. (2015). Comparative assessment of heavy metals in drinking water sources in two small-scale mining communities in northern Ghana. International Journal of Environmental Research and Public Health, 12(9): 10620-10634.

Das, A.P. and Mishra, S. (2008). Hexavalent chromium (VI): Environment pollutant and health hazard. Journal of Environmental Research and Development, 2(3): 386-392.

Dhiman, V. (2020a). Organic Farming for Sustainable Environment: Review of Existed Policies and Suggestions for Improvement. International Journal of Research and Review, 7(2), 22-31.

Dhiman, V. (2020b). Preliminary toxicity assessment of chromium $(\mathrm{Cr})$ and lead $(\mathrm{Pb})$ on terrestrial snail (Helix aspersa). Archives of Agriculture and Environmental Science, 5(1): 67-72, https://doi.org/10.26832/24566632.2020.0501010

Engwa, G.A., Ferdinand, P.U., Nwalo, F.N. and Unachukwu, M.N. (2019). Mechanism and health effects of heavy metal toxicity in humans. In Poisoning in the Modern World-New Tricks for an Old Dog? IntechOpen.

Eskandari, E., Kosari, M., Farahani, M.H.D.A., Khiavi, N.D., Saeedikhani, M., Katal, R. and Zarinejad, M. (2020). A review on polyaniline-based materials applications in heavy metals removal and catalytic processes. Separation and Purification Technology, 231: 115901.

Farooq, M.U. and Jalees, M.I. (2020). Application of Magnetic Graphene Oxide for Water Purification: Heavy Metals Removal and Disinfection. Journal of Water Process Engineering, 33: 101044.

Fisher, R.M. and Gupta, V. (2020). Heavy Metals. In StatPearls [Internet]. StatPearls Publishing.

Flora, S.J.S. (2014). Handbook of arsenic toxicology. Academic Press.

Gomez-Caminero, A., Howe, P.D., Hughes, M., Kenyon, E., Lewis, D.R., Moore, M. and Ng, J. (2001). Arsenic and Arsenic Compounds. World Health Organization.

Hernández, E., Obrist-Farner, J., Brenner, M., Kenney, W.F., Curtis, J.H. and Duarte, E. (2020). Natural and anthropogenic sources of lead, zinc, and nickel in sediments of Lake Izabal, Guatemala. Journal of Environmental Sciences, 96: 117-126.

Hong, P.K.A., Li, C., Jiang, W., Chen, T.-C., and Peters, R.W. (2002). Chelating agents for extraction of heavy metals from soil. 
In Emerging Technologies in Hazardous Waste Management 8, Springer, pp. 9-20.

Inyinbor Adejumoke, A., Adebesin Babatunde, O., Oluyori Abimbola, P., Adelani Akande Tabitha, A., Dada Adewumi, O. and Oreofe Toyin, A. (2018). Water pollution: effects, prevention, and climatic impact. Water Challenges of an Urbanizing World, 33.

Iyer, L.S. and Giri, S.V. (2020). Harnessing technology for mitigating water woes in the city of Bengaluru. In Journal of Physics: Conference Series, Vol. 1427, IOP Publishing, pp. 12004.

Izzo, F., Mercurio, M., de Gennaro, B., Aprea, P., Cappelletti, P., Daković, A. and Langella, A. (2019). Surface modified natural zeolites (SMNZs) as nanocomposite versatile materials for health and environment. Colloids and Surfaces B: Biointerfaces, 182: 110380.

Jaishankar, M., Tseten, T., Anbalagan, N., Mathew, B.B. and Beeregowda, K.N. (2014). Toxicity, mechanism and health effects of some heavy metals. Interdisciplinary Toxicology, 7(2): 60-72.

Jensen, W. (2003). The Place of Zinc, Cadmium, and Mercury in the Periodic Table. Journal of Chemical Education, 80, https://doi.org/10.1021/ed080p952

Jiries, A.G., Al Nasir, F.M. and Beese, F. (2002). Pesticide and heavy metals residue in wastewater, soil and plants in wastewater disposal site near Al-Lajoun Valley, Karak/Jordan. Water, Air, and Soil Pollution, 133(1-4): 97-107.

Kakaei, S., Khameneh, E.S., Hosseini, M.H., and Moharreri, M.M. (2019). A modified ionic liquid clay to remove heavy metals from water: investigating its catalytic activity. International Journal of Environmental Science and Technology, 1-16.

Kennish, M.J. (1996). Practical handbook of estuarine and marine pollution (Vol. 10). CRC press.

Khan, F.S.A., Mubarak, N.M., Khalid, M., Walvekar, R., Abdullah, E.C., Mazari, S.A. and Karri, R.R. (2020). Magnetic nanoadsorbents' potential route for heavy metals removal-a review. Environmental Science and Pollution Research, 1-15.

Khulbe, K.C. and Matsuura, T. (2018). Removal of heavy metals and pollutants by membrane adsorption techniques. Applied Water Science, 8(1): 19.

Koller, M. and Saleh, H.M. (2018). Introductory chapter: introducing heavy metals. Heavy Metals, 13.

Kumar, P.S. and Joshiba, G.J. (2019). Water Footprint of Agricultural Products. In Environmental Water Footprints, Springer, pp. 1-19.

Kumar, V., Singh, J. and Kumar, P. (2019). Heavy metal uptake by water lettuce (Pistia stratiotes L.) from paper mill effluent (PME): experimental and prediction modeling studies. Environmental Science and Pollution Research, 26(14): 14400-14413. https://doi.org/10.1007/s11356-019-04766-2

Lei, L., Song, C., Xie, X., Li, Y. and Fei, W. (2010). Acid mine drainage and heavy metal contamination in groundwater of metal sulfide mine at arid territory (BS mine, Western Australia). Transactions of Nonferrous Metals Society of China, 20(8): 1488-1493.

Lim, K.T., Shukor, M.Y. and Wasoh, H. (2014). Physical, chemical, and biological methods for the removal of arsenic compounds. BioMed Research International, 1-10.

Ma, M., Du, H. and Wang, D. (2019). Mercury methylation by anaerobic microorganisms: A review. Critical Reviews in Environmental Science and Technology, 49(20): 1893-1936.

Ma, Q., Han, L., Zhang, J., Zhang, Y., Lang, Q., Li, F. and Alu, S. (2019). Environmental risk assessment of metals in the volcanic soil of Changbai Mountain. International Journal of Environmental Research and Public Health, 16(11): 2047.

Mandal, P. (2017). An insight of environmental contamination of arsenic on animal health. Emerging Contaminants, 3(1): 17-22.

Masindi, V. and Muedi, K.L. (2018). Environmental contamination by heavy metals. Heavy Metals, 10: 115-132.

Masuda, H. (2018). Arsenic cycling in the Earth's crust and hydrosphere: interaction between naturally occurring arsenic and human activities. Progress in Earth and Planetary Science, 5(1): 68.

Maurya, P.K., Malik, D.S., Yadav, K.K., Kumar, A., Kumar, S and Kamyab, H. (2019). Bioaccumulation and potential sources of heavy metal contamination in fish species in River Ganga basin: Possible human health risks evaluation. Toxicology 
Reports, 6: 472-481.

Mazhar, S.N. and Ahmad, S. (2020). Assessment of water quality pollution indices and distribution of heavy metals in drinking water in Ramganga aquifer, Bareilly District Uttar Pradesh, India. Groundwater for Sustainable Development, 10: 100304.

McKay, WA., Garland, J. A., Livesley, D., Halliwell, C.M. and Walker, M.I. (1994). The characteristics of the shore-line sea spray aerosol and the landward transfer of radionuclides discharged to coastal sea water. Atmospheric Environment, 28 (20): 3299-3309.

Mizerna, K. (2016). Mobility of heavy metals from metallurgical waste in the context of sustainable waste management. Economic and Environmental Studies, 16(4 (40): 819-830.

Moo-Young, M. (2019). Comprehensive biotechnology, Elsevier.

Nayak, M.C., Isloor, A.M., Lakshmi, B., Marwani, H.M. and Khan, I. (2020). Polyphenylsulfone/multiwalled carbon nanotubes mixed ultrafiltration membranes: Fabrication, characterization and removal of heavy metals $\mathrm{Pb}^{2+}, \mathrm{Hg}^{2+}$, and $\mathrm{Cd}^{2+}$ from aqueous solutions. Arabian Journal of Chemistry, 13(3): 4661-4672.

Oliveira, H. (2012). Chromium as an environmental pollutant: insights on induced plant toxicity. Journal of Botany, 1-10

Oviedo, C. and Rodríguez, J. (2003). EDTA: the chelating agent under environmental scrutiny. Quimica Nova, 26(6): 901-905.

Owlad, M., Aroua, M.K., Daud, W.A.W. and Baroutian, S. (2009). Removal of hexavalent chromium-contaminated water and wastewater: a review. Water, Air, and Soil Pollution, 200(1-4): 59-77.

Panichev, N., Mabasa, W., Ngobeni, P., Mandiwana, K. and Panicheva, S. (2008). The oxidation of Cr (III) to Cr (VI) in the environment by atmospheric oxygen during the bush fires. Journal of Hazardous Materials, 153(3): 937-941.

Park, J.-D. and Zheng, W. (2012). Human exposure and health effects of inorganic and elemental mercury. Journal of Preventive Medicine and Public Health = Yebang Uihakhoe Chi, 45(6): 344-352, https://doi.org/10.3961/jpmph.2012.45.6.344

Peng, H., Guo, J., Li, G., Cheng, Q., Zhou, Y., Liu, Z. and Tao, C. (2019). Highly efficient oxidation of chromium (III) with hydrogen peroxide in alkaline medium. Water Science and Technology, 79(2): 366-374.

Pereira, P. and Úbeda, X. (2010). Spatial distribution of heavy metals released from ashes after a wildfire. Journal of Environmental Engineering and Landscape Management, 18(1): 13-22.

Peters, N.E., Meybeck, M. and Chapman, D.V. (2006). Effects of human activities on water quality. Encyclopedia of Hydrological Sciences, 1-10

Pohanish, R.P. (2017). Sittig's handbook of toxic and hazardous chemicals and carcinogens. William Andrew.

Pugazhenthiran, N., Anandan, S. and Ashokkumar, M. (2016). Removal of Heavy Metal from Wastewater - Handbook of Ultrasonics and Sonochemistry. Singapore: Springer Singapore, pp. 813-839, https://doi.org/10.1007/978-981-287-278-4_58

Ragnarsdottir, K.V. (1994). Ejection of trace metals from volcanoes. MinM, 58(2): 752-753.

Ratnaike, R.N. (2003). Acute and chronic arsenic toxicity. Postgraduate Medical Journal, 79(933): 391-396.

Šabanović, E., Memić, M., Sulejmanović, J. and Selović, A. (2020). Simultaneous adsorption of heavy metals from water by novel lemon-peel based biomaterial. Polish Journal of Chemical Technology, 22(1): 46-53.

Saeedi-Jurkuyeh, A., Jafari, A.J., Kalantary, R.R. and Esrafili, A. (2020). A novel synthetic thin-film nanocomposite forward osmosis membrane modified by graphene oxide and polyethylene glycol for heavy metals removal from aqueous solutions. Reactive and Functional Polymers, 146: 104397.

Sanghavi, Y. and Balaji, A. (2013). Water: An imperative human resource. In IEEE Integrated STEM Education Conference (ISEC). IEEE, pp. 1-3.

Selin, N.E. (2009). Global biogeochemical cycling of mercury: a review. Annual Review of Environment and Resources, 34.

Selvi, A., Rajasekar, A., Theerthagiri, J., Ananthaselvam, A., Sathishkumar, K., Madhavan, J. and Rahman, P.K.S.M. (2019). Integrated remediation processes toward heavy metal removal/recovery from various environments-a review. Frontiers 
in Environmental Science, 7: 66.

Shakoor, M.B., Ali, S., Rizwan, M., Abbas, F., Bibi, I., Riaz, M. and Rinklebe, J. (2020). A review of biochar-based sorbents for separation of heavy metals from water. International Journal of Phytoremediation, 22(2): 111-126.

Shankar, S., Shanker, U. and Shikha. (2014). Arsenic Contamination of Groundwater: A Review of Sources, Prevalence, Health Risks, and Strategies for Mitigation. The Scientific World Journal, 304524, https://doi.org/10.1155/2014/304524

Sharma, R., Singh, N.S. and Singh, D.K. (2020). Impact of heavy metal contamination and seasonal variations on enzyme's activity of Yamuna river soil in Delhi and NCR. Applied Water Science, 10(3): 1-8.

Siddiqi, Z.M. (2018). Transport and Fate of Mercury (Hg) in the Environment: Need for Continuous Monitoring BT Handbook of Environmental Materials Management. In C.M. Hussain (Ed.). Cham: Springer International Publishing, pp. 1-20, https://doi.org/10.1007/978-3-319-58538-3_56-1

Sikder, M.T., Kihara, Y., Yasuda, M., Mihara, Y., Tanaka, S., Odgerel, D. and Saito, T. (2013). River water pollution in developed and developing countries: judge and assessment of physicochemical characteristics and selected dissolved metal concentration. CLEAN-Soil, Air, Water, 41(1): 60-68.

Soares, A.L.C., Pinto, C.C. and Oliveira, S.C. (2020). Impacts of anthropogenic activities and calculation of the relative risk of violating surface water quality standards established by environmental legislation: a case study from the Piracicaba and Paraopeba river basins, Brazil. Environmental Science and Pollution Research, 1-15.

Tahir, M.B., Ahmad, A., Iqbal, T., Ijaz, M., Muhammad, S. and Siddeeg, S.M. (2019). Advances in photo-catalysis approach for the removal of toxic personal care product in aqueous environment. Environment, Development and Sustainability, 1-24.

Tandon, S.K. and Khandelwal, S. (1982). Chelation in metal intoxication X: Influence of different polyaminocarboxylic acids and thiol chelators in the excretion and tissue distribution of 54Mn in rat. Research Communications in Chemical Pathology and Pharmacology, 36(2): 337-340.

Torres-Caban, R., Vega-Olivencia, C.A., Alamo-Nole, L., Morales-Irizarry, D., Roman-Velazquez, F. and Mina-Camilde, N. (2019). Removal of copper from water by adsorption with calcium-alginate/spent-coffee-grounds composite beads. Materials, 12(3): 395.

Tran-Ly, A.N., Ribera, J., Schwarze, F.W.M.R., Brunelli, M. and Fortunato, G. (2020). Fungal melanin-based electrospun membranes for heavy metal detoxification of water. Sustainable Materials and Technologies, 23: e00146.

Tripathi, S. S. (2017). Modelling the Effects of Land Use and Land Cover Change on Hydrologic Regime of Ramganga River Basin. Department of Soil Water Land Engineering and Management VAUGUE INSTITUTE.

U.S.E.P.A. (2012). Drinking water standards and health advisories. EPA 822-S-12-001. US Environmental Protection Agency Washington, DC.

Verma, M. (2020). Ecotoxicology of Heavy Metals: Sources, Effects and Toxicity. In Bioremediation and Biotechnology, Vol 2, Springer, pp. 13-23.

Wei, W., Ma, R., Sun, Z., Zhou, A., Bu, J., Long, X., and Liu, Y. (2018). Effects of mining activities on the release of heavy metals (HMs) in a typical mountain headwater region, the Qinghai-Tibet Plateau in China. International Journal of Environmental Research and Public Health, 15(9): 1987.

Wuana, R.A. and Okieimen, F.E. (2011). Heavy metals in contaminated soils: a review of sources, chemistry, risks and best available strategies for remediation. ISRN Ecology, 1-10.

Xu, R., Jian, M., Ji, Q., Hu, C., Tang, C., Liu, R. and Qu, J. (2020). 2D water-stable zinc-benzimidazole framework nanosheets for ultrafast and selective removal of heavy metals. Chemical Engineering Journal, 382: 122658.

Zhao, X.Y., Liang, B., Xiong, K.C., Shi, Y.W., Yang, S.L., Wei, T.Y. and Gai, Y.L. (2020). Two novel lead-based coordination polymers for luminescence sensing of anions, cations and small organic molecules. Dalton Transactions, 49(17): 5695-5702. 
Zhu, Y.G., Xue, X.M., Kappler, A., Rosen, B.P. and Meharg, A.A. (2017). Linking genes to microbial biogeochemical cycling: lessons from arsenic. Environmental Science and Technology, 51(13): 7326-7339.

Cite this chapter as: Dhiman, V., Pant, D., Kumari, S. and Kumar, S. (2020). Recent advances in novel remediation processes towards heavy metals removal from wastewaters. In: Advances in Environmental Pollution Management: Wastewater Impacts and Treatment Technologies, Volume 1, Eds. Kumar, V., Kamboj, N., Payum, T., Singh, J. and Kumar, P., pp. 77-99, https://doi.org/10.26832/aesa-2020-aepm-06 